\title{
Preface: Biogeography and spatial patterns of biodiversity of freshwater phytoplankton
}

\author{
17th workshop of the International Association of Phytoplankton Taxonomy \\ and Ecology (IAP)
}

\author{
Luigi Naselli-Flores · Judit Padisák
}

Published online: 13 October 2015

(C) Springer International Publishing Switzerland 2015

The 17th workshop of the International Association for Phytoplankton Taxonomy and Ecology (IAP) was held in Greece, in the Municipality of Kastoria from 14th to 21st September 2014, and its main ecological theme was the biogeography of phytoplankton and the importance of spatial scales.

The main IAP objectives are to get together preeminent as well as young scientists and students working on various aspects of phytoplankton taxonomy and ecology to discuss topics of current interest, to jointly examine water samples under the microscope and practice species identification under the guidance of

Guest editors: Luigi Naselli-Flores \& Judit Padisák/ Biogeography and Spatial Patterns of Biodiversity of Freshwater Phytoplankton

L. Naselli-Flores $(\bowtie)$

Department of Environmental Biology and Biodiversity, University of Palermo, Via Archirafi, 38, 90123 Palermo, Italy

e-mail: luigi.naselli@unipa.it

J. Padisák

Department of Limnology, University of Pannonia, Egyetem utca 10, Veszprém 8200, Hungary

e-mail: padisak@almos.uni-pannon.hu

J. Padisák

MTA.PE Limnoecology Research Group, Egyetem utca 10, Veszprém 8200, Hungary leading experts, and to encourage young scientists to engage in taxonomy research-a field where expertise is vanishing. Following the traditions of the IAP, close to 100 participants attended the workshop, more or less equally divided between professional scientists and students. The venue where the meeting was held provided a spectacular site located on the shore of Lake Kastoria surrounded by Macedonian mountains. The microscopy sessions in the afternoons were guided by established taxonomists and attended by keen-to-learn young scientists who jointly examined fresh and preserved samples brought by the participants.

The IAP was established in 1979 (Kristiansen, 2003), and since then 16 workshops were held at different locations. Since 1991, each workshop had a well-defined ecological theme, and taxonomic topics. Proceedings of all these workshops have been published in journals with peer-reviewed articles and have played a leading role in advancing phytoplankton community ecology. Since the early 1990s, the following proceedings volumes appeared in special issues of Hydrobiologia:

1991: Baja, Hungary (Padisák et al., 1993)

1993: Mont Rigi, Belgium (Descy et al., 1994)

1996: Granada, Spain (Álvarez-Cobelas et al., 1998)

1998: Shrewsbury, England (Reynolds et al., 2000) 1999: Delta Marsh, Canada (Hamilton et al., 2000) 
2002: Castelbuono, Italy (Naselli-Flores et al., 2003)

2005: Sapanca, Turkey (Albay et al., 2007)

2008: Golan Heights, Israel (Zohary et al., 2010)

2011: S. Michele all'Adige, Italy (Salmaso et al., 2012)

2014: Kastoria, Greece (Naselli-Flores and Padisák, this volume)

As is the tradition for all IAP workshops, the 2014 meeting had two main foci, one was ecological, the other taxonomic. The ecological theme was Biogeography of Phytoplankton and explored the importance of the spatial scale. The taxonomic topic was Cyanobacteria.

Apart from the foreword, the present volume presents a selection of 3 review papers, 1 opinion paper, and 19 original primary research papers. It is structured around the ecological theme of the workshop starting from large to small spatial scales, ending with the within-lake processes. Taxonomic papers review present state of the systematics of planktic cyanobacteria morphometric analyses on heterocytic cyanobacteria and report on the first known trial of barcoding phytoplankton in an entire lake.

We thank the numerous referees who invested their time in preparing reviews for the manuscripts of this special issue and in helping to bring this volume to its present standard. A special thank goes to the publishing and legal units of Springer for their assistance during the publication process.

\section{Luigi Naselli-Flores \& Judit Padisák Guest Editors}

\section{References}

Albay, M., L. Naselli Flores \& J. Padisák, 2007. Morphological plasticity of phytoplankton under different environmental constraints. Hydrobiologia 578: 161.

Álvarez-Cobelas, M., C. S. Reynolds, P. Sanchez-Castillo \& J. Kristiansen, 1998. Phytoplankton and trophic gradients. Developments in Hydrobiology 129: 372. (Reprinted from Hydrobiologia, Vol. 369).

Descy, J.-P., C. S. Reynolds \& J. Padisák, 1994. Phytoplankton in turbid environments: Rivers and shallow lakes. Developments in Hydrobiology 100: 214. (Reprinted from Hydrobiologia, Vol. 289).

Hamilton, P. B., H. Kling \& M. Dokulil, 2000. Cyanoprokaryotes and chlorophytes across trophic gradients. Hydrobiologia 438: 1-264.

Kristiansen, J., 2003. From IAAP to IAP. Hydrobiologia 502: $1-2$.

Naselli-Flores, L., J. Padisák \& M. Dokulil, 2003. Phytoplankton and the equilibrium concept: the ecology of steady state assemblages. Developments in Hydrobiology 172: 416. (Reprinted from Hydrobiologia, Vol. 502).

Padisák, J., C. Reynolds \& U. Sommer, 1993. Intermediate disturbance hypothesis in phytoplankton ecology. Developments in Hydrobiology 81: 200. (Reprinted from Hydrobiologia, Vol. 249).

Reynolds, C. S., M. Dokulil \& J. Padisák, 2000. The trophic spectrum revisited. Developments in Hydrobiology 150: 152. (Reprinted from Hydrobiologia, Vol. 424).

Salmaso, N., L. Naselli-Flores, L. Cerasino, G. Flaim, M. Tolotti \& J. Padisák, 2012. Preface: phytoplankton responses to human impacts at different scales. In: 16th Workshop of the International Association of Phytoplankton Taxonomy and Ecology (IAP) Hydrobiologia 698: 1-3

Zohary, T., J. Padisák \& L. Naselli-Flores, 2010. Phytoplankton in the physical environment. Hydrobiologia 639: 239. 